\title{
PENGARUH LAYANAN KONSELING KELOMPOK DENGAN TEKNIK BEHAVIOR CONTRACT UNTUK MEREDUKSI PERILAKU AGRESIF SISWA KELAS VIII 8 SMP NEGERI 8 KOTA BENGKULU
}

\author{
Egy Guntara, Illawaty Sulian \\ Prodi Bimbingan dan Konseling Fakultas Keguruan dan Ilmu Pendidikan \\ Universitas Bengkulu \\ egyguntara20@gmail.com, illawaty@unib.ac.id.
}

\begin{abstract}
ABSTRAK
Tujuan penelitian ini adalah untuk mendeskripsikan pengaruh layanan konseling kelompok dengan teknik behavior contract terhadap perilaku agresif pada siswa SMP N 08 Kota Bengkulu. Metode dalam penelitian ini adalah metode eksperimen the one group pretestposttest. Populasi dalam penelitian ini adalah siswa kelas VIII 8 SMP N 08 Kota Bengkulu yang berjumlah 33 siswa. Sampel menggunakan teknik purposive samping. Jumlah sampel adalah 6 siswa. Data hasil penelitian ini dianalisis menggunakan uji t. Hasil penelitian menunjukkan bahwa perilaku agresif menurun setelah diberikan layanan konseling kelompok, hal ini ditunjukan dengan nilai $\mathrm{t}=5.874$ dengan taraf signifikasi (2-tailed) sebesar .002 yang berarti $000<0,05$. Temuan ini menunjukkan bahwa ada pengaruh layanan konseling kelompok untuk menurunkan perilaku agresif siswa SMP N 08 Kota Bengkulu.
\end{abstract}

Kata kunci : konseling kelompok, behavior contract, perilaku agresif

\section{THE EFFECT OF GRUOP COUNSELING SERVICE WITH BEHAVIOR CONTRACT TECHNIQUE FOR REDUCING AGGRESSIVE BEHAVIOR STUDENTS GRADE 8 JUNIOR HIGH SCHOOL NUMBER 8 BENGKULU CITY}

\begin{abstract}
The purpose of this research is to descrribe the effect of service group counseling with behavior by the Students grade 8 or junior high school number 08 Bengkulu city, method of this research is experimental the one group pretest-posttest. Population of this reasearch are 33 students and the total sample are 6 students with purposive sampling technique. The result of this research analysis with $\mathrm{T}$ experiment. The result of the research shows aggressive behavior is down after giving group counseling, it is proved by by $\mathrm{T}$ value $=5.874$ eith standard signification (2- tailed) 002 thats mean $000 \leq 0.05$. this finding shows that there are influence aggressive behavior students of junior high school number 08 Bengkulu City.
\end{abstract}

Keywords : Group Counseling, Behavior Contract, Anggressive Behavior. 


\section{Pendahuluan}

Pendidikan merupakan salah satu kebutuhan manusia sepanjang hayat, setiap manusia membutuhkan pendidikan untuk memperluas pengetahuan dan memahami bagaimana bertingkahlaku yang baik. Pendidikan dapat di peroleh melalui pendidikan formal maupun non formal, pada pendidikan formal dan lembaga sekolah yang dirancang khusus dengan pelaksanaan yang terstruktur rapi.

Sekolah sebetulnya tidak sekedar tempat pendidikan formal bagi para siswa namun juga menjadi tempat lingkungan sosial, siswa dalam berbagai situasi di sekolah selalu berhadapan dengan hubungan sosial baik itu didalam kelas, ketika berlangsungnya proses belajarmengajar, ataupun sedang waktu istirahat.

Interaksi dengan teman sebaya merupakan permulaan hubungan persahabatan yang di dalamnya terdapat hubungan timbal balik. Sentosa (2004:79) berpendapat "teman sebaya adalah kelompok anak yang sukses ketika anggotanya dapat berinteraksi". Pengertian teman sebaya di atas dapat di simpulakn bahwa teman sebaya merupakan interaksi pada anak-anak dengan tingkat usia yang sama serta mempunyai tingkat ke akraban yang relatif tinggi di antara kelompoknya.

Agresif merupakan salah satu bentuk perilaku negatif yang terdapat pada individu dengan tujuan menyakiti seseorang, baik secara fisik maupun mental. Menurut patricia D Barry (Yosep, 2007 : 48) agresif adalah suatu keadaan emosi yang merupakan campuran perasaan frustasi dan benci atau marah. Perilaku agresif mempunyai beberapa pendekatan yang dijelaskan oleh beberapa ahli. Para ahli memakai istilah "agresi" sebagai suatu perilaku atau tindakan yang bertujuan untuk melukai secara fisik maupun secara verbal. Dalam konteks ini, kekerasan yang agresif adalah perilaku yang bermaksud untuk melukai objek yang dijadikan sasaran agresitivitas.

Perilaku agresif kini dilakukan oleh berbagai usia baik itu anak-anak, remaja maupun orang dewasa, bahkan lansia. Perilaku agresif ini pula dilakukan oleh perseorangan maupun kelompok. Tidak jarang kita melihat sendiri perilaku agresif tersebut, bahkan mungkin kita sendiri yang menjadi pelaku perilaku agresif tersebut. Perilaku agresif bertentangan dengan norma-norma yang berlaku di lingkungan . perilaku agresif tersebut merugikan perkembangan dirinya dalam hal keamanan dan kenyamanan orang lain. Dampak perilaku agresif tidak hanya mempengaruhi emosi dan perilaku, tetapi mempengaruhi prestasi, dan bersosialisasi pada masyarakat. 
Agresif menurut Baron (dalam Mahmuda, 2011: 61) adalah bentuk perilaku di sengaja terhadap makluk hidup lain dengan tujuan untuk melukai atau membinasakan dan orang yang di serang berusaha untuk meghindar. Sehingga agresif dapat diartikan sebagai sebuah perilaku yang bertujuan untuk melukai seseorang baik secara verbal maupun non-verbal.

Berdasarkan hasil wawancara dan observasi lapangan dengan guru BK di SMP Negeri 8 Kota Bengkulu pada bulan November 2018, terdapat beberapa siswa- siswi di SMP Negeri 8 melakukan perilaku agresif terhadap temannya yang di anggap sebagi musuh. Data terhimpun dari catatan guru BK dan laporan dari guru mata pelajaran. Perilaku agresif yang di lakukan seperti: beberapa siswa sering meng olok-olok satu sama lain, siswa melakukan serangan fisik seperti menendang, memukul satu sama lain, dan siswa menyebarkan opini negtif melalui ucapan dari teman ke teman. Permasalahan di atas menunjukan bahwa masih banyak siswa yang berbuat seenaknya sendiri di sekolah. Apabila keadaan demikian terus di biarakan dan tidak segera di atasi oleh pihak sekolah maka bisa saja keadaan tersebut akan membudaya dan pada akhirnya akan merugikan siswa dan sosial masyarakat di sekitar siwa itu sendiri.

Perilaku agresif siswa dapat dientaskan melalui layanan konseling kelompok menggunakan teknik behavior countract. Layanan konseling kelompok dengan teknik behavior contract diberikan kepada siswa yang melakukan perilaku termasuk agresif dalam anggota konseling kelompok. Behavior contract atau kontrak perilaku adalah persetujuan antara dua orang atau lebih (konselor dan konseli) untuk mengubah perilaku tertentu pada konseli. Konselor dapat memilih perilaku yang realistik dan dapat diterima oleh kedua belah pihak. Setelah perilaku dimunculkan sesuai dengan kesepakatan, ganjaran dapat diberikan kepada konseli (Latipun, 2010: 95). Pada penelitian ini, teknik kontrak perilaku diberikan dalam layanan konseling kelompok yaitu pada tahap kegiatan layanan konseling kelompok.

Berdasarkan urayan latar belakang di atas, maka munculah ketertarikan penulis untuk melakukan penelitian dengan judul "Pengaruh Layanan Konseling Kelompok Dengan Teknik Behavior Contract Untuk Mereduksi Perilaku Agresif Siswa Kelas VIII 8 SMP Negeri 8 Kota Bengkulu".

\section{Metode Penelitian}

Penelitian ini adalah penelitian eksperimen. Dalam penelitian eksperimen harus terdapat perlakuan (treatment) yaitu sesuatu yang mungkin menjadi penyebab. Dalam 
penelitian ini treatmen yang diberikan adalah layanan konseling kelompok dengan teknik behavior countract dalam mengurangi prilaku agresif siswa. Desain penelitian yang digunakan dalam penelitian ini adalah metode eksperimen dengan one-group pre-test posttest design karena penelitian ini tidak menggunakan kelompok pembanding.

Melalui desain ini penelitian dilakukan hanya pada satu kelompok dengan melakukan dua kali pengukuran yaitu pengukuran yang pertama $\mathrm{O} 1$ (pre test) untuk mengukur tingkat agresif siawa yang di sebabkan oleh teman sebaya sebelum diberikan layanan bimbingan konseling kelompok. Pengukuran yang kedua $\mathrm{O} 2$ (post test) untuk mengukur tingkat agresif siawa yang di sebabkan oleh teman sebaya setelah diberi layanan bimbingan konseling kelompok.

Sampel adalah sebagian dari populasi, sebagai contoh yang diambil dengan menggunakan cara-cara tertentu (Zuriah, 2009: 119). Sugiyono (2015: 34), menjelaskan, sampel adalah sebagian atau wakil populasi yang diteliti. Adapun sampel dalam penelitian ini adalah 6 orang siswa kelas VIII 8 SMP Negeri 8 Kota Bengkulu yang mengalami prilaku agresif diperoleh dari hasil pengisian angket perilaku agresif. Pengambilan subjek dalam penelitian ini, peneliti akan memberikan pre-test sebelum diberikan layanan konseling kelompok dengan teknik behavior countaract dan post-test setelah diberikan layanan konseling kelompok dengan teknik behavior countract.

Sampel pada penelitian diperoleh dengan melakukan penyebaran instrument pada kelas yang menjadi populasi yakni kelas VIII 8 yang berjumlah 33 orang. Berdasarkan hasil olah instrumen didapatkan 6 orang siswa dalam skor angresif tertinggi dikelas tersebut yang kemudian dijadikan sampel pada penelitian ini. Teknik pengunpulan data pada penelitian ini menggunakan angket/kuisioner.

Angket/ kuisioner, merupakan instrumen/alat untuk mendapatkan data siswa melaui butir-butir pertanyaan yang harus dijawab oleh siswa. kuisioner adalah serangkaian pertanyaan yang disusun secara responden dan kemudian setelah diisi dikembalikan ke peneliti. Angket ini bertujuan untuk mengungkap tingkat prilaku agresif siswa. Prilaku agresif di ukur dengan instrumen yang berisi pernyataan tentang perilaku agresif. Pengambilan data dengan mengunakan skala likert yang terdiri dari empat respon jawaban yaitu: sangat sesuai (SS), sesua (S), tidak sesuai (TS), sangat tidak sesuai ( STS). Skor timggi dalam pernyataan negatif menunjukan bahwa tingkat agresif yang terjadi rendah, sebaliknya apabila skor tinggi dalam pernyataan positif menunjukkan bahwa prilaku agresif yang terjadi tinggi. 
Pengujian validitas menguji instrument yang dipilih, apakah memiliki tingkat ketepatan untuk mengukur apa yang semestinya diukur. Validitas adalah suatu ukuran yang menunjukkan tingkatan - tingkatan keterpercayaan dari instrumen yang digunakan dalam penelitian Arikunto (2010: 211). Dalam menguji validitas item instrumen dengan menggunakan program komputer paket Statistical Packages for Sosial Science (SPSS) for Windows Release 16.

\section{Hasil dan Pembahasan}

Deskripsi data yang disajikan dalam penelitian ini adalah dengan deskripsi data dari tingkat prilaku agresif siswa sebelum, sesudah dan cara layanan konseling kelompok dengan teknik behavior contract guna mereduksi prilaku agresif pada siswa. Instrumen pengumpul data akan diuji reliabilitasnya menggunakan program komputer paket Statistical Packages for Sosial Science (SPSS) for Windows Release 16. Untuk mengukur reliabilitas digunakan rumus Alpha Cronbach. Dalam pengukuran reabilitas didapatkan Alpha Cronbach 0,924 yang berarti reabilitas dari angngket tersebut sangat baik.

Perlakuan yang diberikan pada penelitian ini adalah konseling kelompok mengunakan teknik behavior contracat dengan 6 kali pertemuan. Pada setiap pertemuan membahas masalah pribadi siswa yang berprilaku agresif. Untuk menguji hipotesis, data-data yang terkumpul dianalisis secara statistik dengan menggunakan bantuan penghitungsn komputerisasi SPSS.

Dalam menentukan kategori perolehan skor siswa yang berprilaku agresif, diawali dengan mencari mean dan standard deviasi. Hasil data penelitian untuk pengukuran diperoleh data mean sebesar 87, 5 ,standar deviasi sebesar 17,5 ,dengan skor minimum 35 dan skor maksimum sebesar 140. Pengukuran menggunakan 5 kategori. Kategori tersebut adalah sangat tinggi, tinggi, sedang, rendah dan sangat rendah. Dalam menentukan kategori perolehan skor siswa yang mengalami stress akademik, diawali dengan mencari mean dan standard deviasi dengan menggunakan software statistical packages fos social science (SPSS) versi 16.

Tabel 1

\section{Frekuensi Pre-Test Prilaku Agresif}

\begin{tabular}{ccc}
\hline Interval & Frekuensi & Persentase \\
\hline Sangat Tinggi $\geq 123$ & 2 & $33 \%$ \\
\hline Tinggi $101-122$ & 4 & $67 \%$ \\
\hline Sedang 79-100 & 0 & 0 \\
\hline
\end{tabular}




\begin{tabular}{ccc}
\hline Rendah 57-78 & 0 & 0 \\
\hline Sangat Rendah $\leq 56$ & 0 & 0 \\
\hline Total & 6 & $100 \%$ \\
\hline
\end{tabular}

Hasil pengambilan data awal (pre-test) sesuai dengan tabel 1, diperoleh siswa yang dikategorikan memiliki perilaku agresif tinggi 4 orang, dan 2 orang siswa memiliki perilaku agresif sangat tinggi, dan tidak ada siswa yang memiliki perilaku agresif yang dalam tingkatan sedang, rendah, sangat rendah.

Berdasarkan tabel 1 diketahui bahwa perilaku agresif siswa SMP N 08 Kota Bengkulu tergolong tinggi. Seperti di tunjukan tidak terdapat siswa yang memiliki prilaku agresif rendah. Siswa dalam kategori memiliki prilaku agresif sangat tinggi dengan skor $(\geq 123)$ berjumlah 2 orang dengan persentase 33\%. Siswa dalam kategori memiliki prilaku agresif tinggi dengan skor ( $101-122$ ) berjumblah 4 orang dengan persentase 67\%. Hal ini menunjukan bahwa siswa SMP N 8 Kota Bengkulu memiliki prilaku agresif tergolong tinggi sebelum di berikan treatmen layanan konseling kelompok.

\section{Tabel 2}

Frekuensi post-test tingkat perilaku agresif

\begin{tabular}{ccc}
\hline Kategori & Frekuensi & Persentase \\
\hline Sangat Tinggi & 0 & 0 \\
\hline Tinggi & 0 & 0 \\
\hline Sedang & 3 & $50 \%$ \\
\hline Rendah & 3 & $50 \%$ \\
\hline Sangat Rendah & 0 & 0 \\
\hline Total & 6 & $100 \%$ \\
\hline
\end{tabular}

Hasil post-test pada tabel 2, sudah tidak ada lagi siswa yang memiliki perilaku agresif yang masuk dalam kategori sangat tinggi dan tinggi. Dari 6 orang siswa yang telah diberikan treatment atau layanan konseling kelompok diketahui bahwa 3 orang siswa memiliki tingkat perilaku agresif yang sedang, dan 3 orang siswa memiliki tingkat prilaku agresif yang rendah.

Berdasarkan tabel 2, diketahui bahwa perilaku agresif siswa SMP N 08 Kota Bengkulu setelah diberikan perlakuan sudah tidak ada lagi yang masuk ke dalam kategori sangat tinggi dan tinggi. Sehingga siswa SMP N 08 Kota Bengkulu hanya terbagi menjadi 2 kategori yakini siswa dengan perilaku agresif sedang dan rendah. Siswa yang memiliki perilaku agresif dalam kategori sedang dengan skor yang didapat (79-100) sebanyak 3 orang (50\%) dan kategori rendah dengan skor yang didapat (57-78) sebanyak 3 orang (50\%). Hal ini menunjukkan bahwa hasil post-test 6 siswa yang diberikan treatment memiliki perilaku 
agresif yang rendah setelah diberikan treatment layanan konseling kelompok dengan mengunakan teknik behavior contract.

Tabel 3

Perbandingan skor pre-test dan post-test perilaku agresif

\begin{tabular}{|c|c|c|c|c|c|c|}
\hline \multirow[t]{2}{*}{ NO } & \multirow[t]{2}{*}{ RESP } & \multicolumn{4}{|c|}{ HASIL } & \multirow[b]{2}{*}{ PENURUNAN } \\
\hline & & $\begin{array}{l}\text { PRE- } \\
\text { TEST }\end{array}$ & KATEGORI & $\begin{array}{c}\text { POST- } \\
\text { TEST }\end{array}$ & KATEGORI & \\
\hline $\mathbf{1}$ & $\mathrm{RS}$ & 117 & Tinggi & 84 & Sedang & 33 \\
\hline 2 & RI & 120 & Tinggi & 92 & Sedang & 28 \\
\hline 3 & TO & 120 & Tinggi & 62 & Rendah & 58 \\
\hline 4 & MA & 127 & $\begin{array}{l}\text { Sangat } \\
\text { Tinggi }\end{array}$ & 61 & Rendah & 66 \\
\hline 5 & VM & 126 & $\begin{array}{l}\text { Sangat } \\
\text { Tinggi }\end{array}$ & 67 & Rendah & 59 \\
\hline 6 & $\mathrm{AG}$ & 111 & Tinggi & 88 & Sedang & 23 \\
\hline \multicolumn{2}{|c|}{ TOTAL } & 613 & & 454 & & 267 \\
\hline \multicolumn{2}{|c|}{ Tertinggi } & 127 & & 92 & & 35 \\
\hline \multicolumn{2}{|c|}{ Terendah } & 111 & & 61 & & 50 \\
\hline \multicolumn{2}{|c|}{ Mean } & 119 & & 76.5 & & 42,5 \\
\hline \multicolumn{2}{|c|}{ SD } & 2.7 & & 5.1 & & \\
\hline
\end{tabular}

Tabel 3 menunjukkan perbedaan skor dan mean pre-test dan post-test tingkat perilaku agresif, yang diketahui pada skor pre-test sebanyak 4 siswa (RS, RI, TO, AG) memiliki tingkat perilaku tinggi dan 2 siswa (MA, VM) berkategori sangat tinggi, dengan rata-rata tingkat perilaku agresif tinggi ditunjukan dengan mean 119 yang berkategori tinggi. Kemudian setelah diberikan treatment, skor hasil post-test didapatkan 3 siswa (MA, MV, TO) memiliki perilaku agresif rendah dan 3 siswa (RS, RI, AG) berkategori sedang, dengan rata-rata perilaku agresif rendah ditunjukkan mean 76.5. Dapat disimpulkan bahwa ada penurunan tingkat perilaku agresif setelah diberikan treatment konseling kelompok dengan teknik behavior countract.

\section{Tabel 4}

Hasil Penelitian Analisis Paired-Sample T-Test

\begin{tabular}{ccc}
\hline & $T$ & Sig. \\
\hline Pre-test-Post-test & 5.874 & .002 \\
\hline
\end{tabular}

Berdasarkan tabel 4 dapat dijelaskan bahwa nilai post-test lebih kecil dari nilai pre-test. Pada tabel 4, hasil uji T-Test sebesar 5.874 dan Sig .002 yang artinya ada perbedaan yang signifikan penurunan tingkat perilaku agresif siswa sebelum dan sesudah diberikan layanan. Berarti ada pengaruh layanan konseling kelompok untuk mengurangi tingkat perilaku agresif 
pada siswa. Maka hipotesis $\left(\mathrm{H}_{0}\right)$ ditolak dan $\left(\mathrm{H}_{\mathrm{a}}\right)$ diterima. Dapat disimpulkan bahwa ada penurunan perilaku agresif siswa SMP N 08 Kota Bengkulu melalui layanan konseling kelompok teknik behavior contract. Berdasarkan hasil Uji t menyimpulkan bahwa adanya pengaruh layanan konseling kelompok dengan menggunakan teknik behavior contract.

Perilaku agresif adalah sebagai perilaku yang dimaksudkan untuk menyalahkan atau mencederai orang lain. Perilaku agresif hampir sama dengan kekerasan. Indikator yang akan diteliti berkaitan dengan aspek yang mempengaruhi prilaku agresif yang dikemukan oleh Buus (dalam Tri Dayaknisi dan Hudaniah, 2009:188-189) yaitu agresif verbal aktif lansung, agresif verbal pasif langsung, agresif verbal aktif tidak langsung, agresif verbal pasif tidak langsung, agresif fisik aktiv langsung, agresif fisik pasif langsung, agresif fisik aktif tidak langsung dan agresif fisik tidak langsung. Prilaku agresif di ukur dengan instrumen yang berisi pernyataan tentang perilaku agresif. Pengambilan data dengan mengunakan skala likert yang terdiri dari empat respon jawaban yaitu: sangat sesuai (SS), sesua (S), tidak sesuai (TS), sangat tidak sesuai ( STS). Skor timggi dalam pernyataan negatif menunjukan bahwa tingkat agresif yang terjadi rendah, sebaliknya apabila skor tinggi dalam pernyataan positif menunjukkan bahwa prilaku agresif yang terjadi tinggi.

Adanya layanan konseling kelompok dengan teknik behavior contract ini dapa mengurangi prilaku agresif yang dilakuka oleh siswa metode layanan ini dapat dilakukan kembali atau diterapka kembali oleh guru BK di sekolah guna mereduksi prlaku agresif.

\section{Kesimpulan}

Perilaku agresif yang pada siswa SMP N 08 Kota Bengkulu sebelum diberikan layanan konseling kelompok masih tergolong dikategorikan perilaku agresif tinggi. setelah diberikan layanan konseling kelompok mengalami penurunan, ini terlihat dari rata-rata post-test yaitu pada kategori perilaku agresif bernilai rendah. terlihat dari rata-rata post-test yaitu dalam katagori rendah. Terdapat pengaruh layanan konseling kelompok dalam menurunkan tingkat perilaku agresif yang mengalami pada siswa kelas VIII-8 di SMP N 08 Kota Bengkulu. Hal ini dapat dibuktikan dari hasil analisis data yang menyebutkan bahwa $\mathrm{H}_{0}$ ditolak yang berarti terdapat pengaruh dalam pemberian layanan untuk menurunkan perilaku agresif siswa.

\section{Daftar Pustaka}

Arikunto. (2010). Prosedur Penelitian: Suatu Pendekatan Praktek. Jakarta: Rineka Cipta. Baron \& Robert, B. (2009). Psikologi sosial. Jakarta: Erlangga 
Dayakisni, T. \& Hudaniah. (2009). Psikologi sosial. Malang: UMM Press.

Latipun. ( 2008). Psikologi Konseling. UMM Press.

Prayitno \& Amti, E. (2004). Dasar-dasar Bimbingan dan Konseling. Jakarta: Rineka Cipta. Purwasih, R. (2017). Hubungan Kompetensi Kontrol Diri Terhadap Kecenderungan Perilaku Agresif Siswa Smk Bengkulu Utara. Jurnal consilia. Vol. 1. No.1, 2017, 5558.

Sentosa (2004). Kelompok teman sebaya. Jakarta: Alfabeta.

Sugiyono. (2015). Metode penelitian kuantitatif kualitatif dan $R \& D$. Bandung: CV.

Sugiyono. (2015). Metode Penelitian Pendidikan. Bandung: Alfabeta.

Zuriah \& Nuzul. (2009). Metodologi Penelitian Sosial Pendidikan Teori-Aplikasi, Jakarta: PT Bumi Aksara. 